\title{
Taalrubriek_TGW_04
}

\section{Oor die skryfwyse van Afrikaans II}

In die vorige rubriek het ek uit die eerste Afrikaanse woordelys en spelreëls (AWS), wat in 1917 verskyn het, aangehaal en op grond daarvan probeer aantoon hoe die skryfwysestelsel van Standaardafrikaans basies werk. Dié beginsels is die volgende: "Wanneer die een of ander woordsoort - behalwe 'n bijvoeglikenaamwoord - 'n selfstandige naamwoord nader bepaal, word die twee aaneengeskrijwe: noordpool, seewater, môreson, uitspanplek."

Ek het toe gesê ons gaan later na enkele uitsonderings op hierdie twee reëls kyk.

Hoewel byvoeglike naamwoorde (b.nw.) gewoonlik los geskryf word van die selfstandige naamwoord (s.nw.) wat hulle bepaal ( $A W S^{1}$ reël 14.27) - bv. wilde kat, rooi Ferrari, koue kos, lang droogte, moedelose rektore - is daar wel gevalle waarin ons tradisioneel die b.nw. vas skryf aan die s.nw. wat hy bepaal.

Die eerste van hierdie uitsonderings is die gevalle van sogenaamde betekenisverdigting (AWS r. 14.31), d.w.s. dat'n bepaalde kombinasie van b.nw. en s.nw.'n sekere spesiale betekenis kry en so dikwels só saamgebruik word dat die twee as 't ware aan mekaar vasgroei. Dit behels gevalle soos die bekende donkerkamer (waarin fotografiese films ontwikkel is/word), geelwortel (bepaalde groentesoort), suurlemoen (soort sitrusvrug) en so meer.

By betekenisverdigting moet 'n mens 'n paar goed onthou. Dit is naamlik nie slegs dat 'n sekere kombinasie gereeld voorkom nie, of slegs dat so 'n kombinasie 'n gespesialiseerde betekenis het nie. Daar moet ook redelikerwys 'n betekenisverskil tussen die los geskrewe en die vas geskrewe kombinasie aangetoon kan word (of minstens histories aangetoon kon word). So staan donkerkamer (m.b.t. fotografie) teenoor donker kamer (enige kamer wat min lig kry), geelwortel (groentesoort) teenoor geel wortel (enige wortel wat geel van kleur is), suurlemoen (Citrus' limon) teenoor suur lemoen ( $C$.' sinensis wat nie soet is nie).

Hierdie opposisie is belangrik, want 'n mens sien dikwels dat kombinasies van b.nw. + s.nw. vas geskryf word bloot omdat dit 'n gespesialiseerde of uitsonderlike of vreemderige betekenis het. So sien mens dikwels ten onregte * groenenergie bloot omdat dit vreemd is om 'n kleurnaam met "energie" te kombineer. Wat hier gebeur, is dat "groen" 'n betekenisuitbreiding ondergaan het en nou ook "omgewingsvriendelik, ekovriendelik" of iets dergeliks beteken.

Volgens hierdie argument, sou 'n mens dus kon redeneer dat dit wel geregverdig is om groengebou ("gebou ontwerp volgens ekovriendelike beginsels/groen argitektuur") te skryf omdat dit teenoor groen gebou ("gebou wat groen geverf is") kan staan. 'n Mens moet egter onthou dat betekenisverdigting altyd'n proses behels, en dit bring mee dat dit nie altyd duidelik is dat betekenisverdigting al in so 'n mate plaasgevind het dat die moedertaalsprekers reeds die skryfwyse- (en die gepaardgaande uitspraak-) verskil aanvoel en toepas nie. So byvoorbeeld kan groenvye vir sommige beteken "konfyt van voorvye gekook" of die voorvye self, terwyl ander dit steeds as groen vye aanvoel.

Daarom moet ons ook nie bloot op grond van 'n aantoonbare betekenisverskil tussen byvoorbeeld groengebou en groen gebou as 't ware "betekenisverdigting" afdwing of ryp druk

\footnotetext{
Verwysings is na die tiende uitgawe van die $A W S, 2009$.
} 
nie. Ons moet die proses en die natuurlike ontwikkeling respekteer. Die geval van die internasionale reddingsorganisasie die Rooi Kruis/Rooikruis en die bynaam Rooi Leër van die destydse USSR-leër illustreer juis (a) dat dit 'n proses is, want vir sommige is dit RooiKruis, terwyl andere dit reeds as Rooikruis sien, en (b) dat betekenisverdigting nie noodwendig altyd plaasvind nie.

Daar kan dus twyfel bestaan oor die skryfwyse van sommige sulke kombinasies, en dit moet dan nie as 'n fout beskou word as party mense vas skryf wat ander los skryf nie. Dit is egter belangrik dat ons nie sommer goedsmoeds 'n b.nw. vas aan 'n s.nw. skryf bloot omdat dit 'n ongewone kombinasie met 'n "spesiale betekenis" is nie.

Die tweede soort geval waarin 'n b.nw. vas aan 'n s.nw. geskryf word, is die sg. samestellende samestelling ( $A W S$ rr. 12.6, 14.26).

Hier moet'n mens eers sê dat elke samestelling bestaan uit' $n$ kern (dit wat die samestelling eintlik of wesenlik benoem) en minstens een bepaler. In seker $99,9 \%$ van gevalle is die kern van 'n samestelling die laaste deel daarvan. In byvoorbeeld koekblik is "blik" die kern, want dit benoem die voorwerp wesenlik as 'n blik, en "koek" is die bepaler, want dit "beskryf" watter soort blik dit is.

Indien 'n b.nw. op die gewone manier 'n samestelling bepaal ( $A W S$ r. 14.27), bepaal hy wesenlik die kern. In "ronde/mooi koekblik" het die b.nw. ronde of mooi dus betrekking op blik, nie op koek nie.

Soms gebeur dit egter dat'n woordgroep (dus los geskrewe woorde) soos hoër onderwys of hoё hak gesamentlik as bepaler van 'n s.nw. optree, byvoorbeeld onderskeidelik sektor of skoene. Wanneer dié drie nou tot 'n samestelling gekombineer word, bly "sektor" en "skoene" die kern, maar die b.nw. bepaal nou nie meer die kern-s.nw. nie, maar wel die eerste s.nw., wat deel van die bepaler is. Om te voorkom dat die b.nw. nou die verkeerde (laaste) s.nw. bepaal, word hy vas geskryf aan die s.nw. wat hy wel bepaal. Dus "hoë" bepaal "hak" en saam bepaal hulle "skoene": hoëhakskoene, of "hoër" bepaal "onderwys" en saam bepaal hulle "sektor", wat hoëronderwyssektor gee. Kyk AWS r. 12.6 opm. (c).

Wat hier van b.nwe. gesê word, geld eweneens telwoorde, bv. eersteministerskantoor of tweewielfiets.

Indien 'n mens in laasgenoemde geval die b.nw. los sou skryf, bepaal hulle die kern."Hoë" sal dus "skoene" bepaal, en dan verander die betekenis van "skoene met hoë hakke" na "hakskoene wat hoog is", en "hoër onderwyssektor" beteken dan "n onderwyssektor wat hoër as 'n ander is", in plaas van "die sektor van/vir hoër onderwys". As 'n mens dus gekonfronteer word met die vraag hoe 'n bepaalde kombinasie van b.nw./telw. + s.nw. + s.nw. geskryf moet word, moet jy eers vasstel watter een van die twee s.nwe. die b.nw. of telw. bepaal. As hy die eerste s.nw. bepaal, word die hele kombinasies as een samestelling geskryf, en as hy die tweede s.nw. (die kern) bepaal, bly die b.nw./telw. soos gewoonlik los.

Dus: groenvyekonfyt is konfyt gemaak van groen vye/groenvye, maar groen vyekonfyt is vyekonfyt wat om die een of ander rede groen is ('n arige gedagte), en twintigliterhouers is houers met' $n$ inhoudsmaat van $20 \ell$, maar twintig literhouers is 20 houers met' $n$ inhoudsmaat van $1 \ell$ elk. (Vir die skryfwyse van samestellings wat syfers, getalle of simbole bevat, kyk veral $A W S$ rr. 7.1-7.17.)

Die gebruik van koppeltekens in sulke samestellende samestellings hang af van veral verwarrende klinkerkombinasies by "verbindingspunte" of "koppelvlakke", die lengte van die samestelling en dergelike. Kyk AWS rr. 12.6 opmm. (a) en (b).

In die volgende rubriek kyk ons na nog twee besondere soorte samestellings waarin b.nwe. optree, te wete afstandsamestellings en gewone name van plante en diere. 
Lesers wat nie 'n $A W S$ besit nie, word weer aangemoedig om hierdie belangrike Akademiepublikasie aan te skaf. Dit sal Afrikaansskrywendes beslis baat om die Spelreëls-afdeling daarvan minstens aandagtig deur te blaai sodat hulle kan kennis neem van wat daarin bereël word, en dan is die Woordelys- en die Afkortingslys-afdeling natuurlik nuttige kitsnaslaanbronne. Die $A W S$ is heel toeganklik via die inhoudsopgawe, die indeks agterin, interne kruisverwysings, 'n termlys, en so meer. 